\title{
Kualitas Dange yang Disubstitusi Tepung Daging Ikan Kembung (Rastrellinger kanagurta)
}

\author{
DOI 10.18196/pt.2014.020.28-35
}

\author{
Ambar Rukmini*, Kuntjahjawati, dan Supriasri \\ Fakultas Teknologi Pertanian, Universitas Widya Mataram Yogyakarta, Dalem Mangkubumen KT III/237 Yogyakarta 55132 \\ *Corresponding author, e-mail:ambar_rukmini@yahoo.co.uk
}

\begin{abstract}
ABSTRAK
Dange adalah makanan tradisional yang terbuat dari pati sagu basah yang dihaluskan dan dipanggang dalam forna. Dange memiliki bentuk empat persegi panjang yang pipih dengan ketebalan \pm 0,5 cm. Dange bersifat keras, ringan dan rasanya tawar, relatif tidak higroskopis dan cepat mengembang jika dicelupkan dalam cairan. Penelitian ini bertujuan menentukan konsentrasi tepung daging ikan kembung yang dapat disubstitusikan serta lama waktu pemanggangannya terhadap kualitas dange yang dihasilkan.Penelitian dirancang menggunakan rancangan acak lengkap faktorial $4 \times 3$. Faktor pertamakonsentrasi tepung daging ikan (0\%, 2\%, 5\% dan 8\%), faktor kedua waktu pemanggangan (1 menit, 2 menit dan 3 menit). Analisis kimia yang dilakukan meliputi penentuan kadar air, kadar lemak, kadar abu, kadar protein serta kadar pati.Analisis organoleptik menggunakan metode scoring test serta uji kesukaan keseluruhan, menggunakan metode hedonic scale test. Hasil penelitian menunjukkan dange yang dibuat dengan substitusi 5\% tepung daging ikan kembung dan waktu pemanggangan 1 menit merupakan dange yang paling disukai panelis. Dange tersebut mempunyai karakteristik tekstur agak rapuh, warna putih kekuningan, cita rasa ikan serta aroma khas ikan agak kuat dengan kadar air 27,84\% ; kadar protein 3,98\% db ; kadar lemak 0,50\% db ; kadar abu 2,48\% db dan kadar pati 57,78\% db.

Kata kunci: Dange, substitusi, tepung daging ikan, analisis kimia, analisis sensorik
\end{abstract}

\section{ABSTRACT}

Dange is a traditional food made from delicate wet sago starch and further roasted in forna. Dange has rectangle form, flat with approximately 0,5 cm thickness. In addition, dange is also well known for its light, tasteless, hardness and relatively not hygroscopy. To increase the quality of dange and improve its flavour, a research was performed to study the quality of dange substituted with mackerel fish meat. The treatment was arranged in two classifications factorial completely randomized design. The classifications were variation of mackerel fish meat (0\%, 2\%, 5\% and 8\%) and time of grill (1 minute, 2 minutes and 3 minutes). Furthermore, the dangeproduct quality was tested chemical and sensory analysis. The chemical analysis consisted of moisture, protein, fat, ash and starch content. Whereas the differentof dange product quality was tested sensory analysis using scoring test method and the consumers acceptance was tested by hedonic scale test method.It was found that the most liked dange was madefrom 5\% substitute of mackerel fish meat at 1 minute grill. This dange had slightly brittle texture, yellow-white colour, fishy taste and relatively strong fishy flavour with 27.84\% moisture, 3.98\% protein, 0.50\%fat, 2.48\% ash and 57,78\% starch content.

Key words : dange, substitution, mackerel fish meat, chemical analysis, sensory analysis.

\section{PENDAHULUAN}

Dange (sagu lempeng) merupakan makanan tradisional daerah Indonesia bagian timur, seperti Maluku, Papua dan Palopo (Sulawesi Selatan). Jenis pangan tersebut, di Jawa Barat dikenal sebagai Sagu Ambon. Dange dibuat dari pati sagu basah atau setengah kering yang diremahkan (dihaluskan). Pati sagu yang digunakan biasanya diambil dari tumang atau berasal dari pati sagu kering yang dibasahi sampai mencapai kadar air tertentu hingga menyerupai sagu tumang. Tumang adalah tempat sagu basah yang terbuat dari anyaman daun sagu. Untuk mendapatkan bentuk remah dan halus, pati sagu basah diayak dengan cara menggosok-gosokkan bongkah-bongkah pati di atas ayakan. Hasil ayakan bongkahan pati tersebut diayak lagi hingga diperoleh bagian pati yang remah dan halus yang selanjutnya siap dimasak dan dicetak dengan alat yang disebut forna. 
Dange pada umumnya berbentuk empat persegi panjang yang pipih dengan ketebalan \pm $0,5 \mathrm{~cm}$. Jenis pangan tersebut bersifat keras, ringan dan rasanya tawar, relatif tidak higroskopis dan cepat mengembang jika dicelupkan dalam cairan. Dange biasa dikonsumsi setelah dicelupkan dalam kopi, teh atau minuman lainnya. Namun, dapat pula dicelupkan dalam air hingga lembek, kemudian dikonsumsi dengan lauk ikan dan sayur.

Kandungan zat gizi yang utama dalam dange adalah karbohidrat. Zat gizi lainnya, seperti protein sangat rendah. Oleh karena itu, perlu diperkaya dengan protein. Pangloli dan Bambang (1992) telah mencoba melakukan fortifikasi dange dengan tepung susu skim dan tepung kedelai. Upaya fortifikasi tersebut dapat meningkatkan kandungan protein dange. Namun, dilihat dari nilai ekonomisnya, harga susu skim relatif mahal. Fortifikasi dengan tepung kedelai ternyata menemui kendala, yaitu timbulnya bau langu yang dapat menurunkan akseptabilitasnya. Oleh karena itu perlu dicari alternatif lain yang lebih memungkinkan, antara lain menggunakan tepung daging ikan.

Pembuatan dange dengan campuran tepung daging ikan dilakukan mengingat Indonesia bagian timur merupakan daerah penghasil ikan. Jenis ikan yang mudah diperoleh dalam jumlah banyak, mempunyai rasa dan aroma khas serta harganya relatif murah adalah ikan kembung (Rastrellinger kanagurta). Selain itu, ikan tersebut memiliki tulang sedikit dan mudah hancur jika ditepungkan. Untuk mendapatkan dange dengan carnpuran tepung daging ikan yang berkualitas, perlu dicari formulasi dan proses pengolahan yang tepat. Oleh karena itu, perlu diteliti variasi konsentrasi tepung daging ikan yang dapat disubstitusikan serta variasi lama waktu pemanggangannya karena faktor tersebut

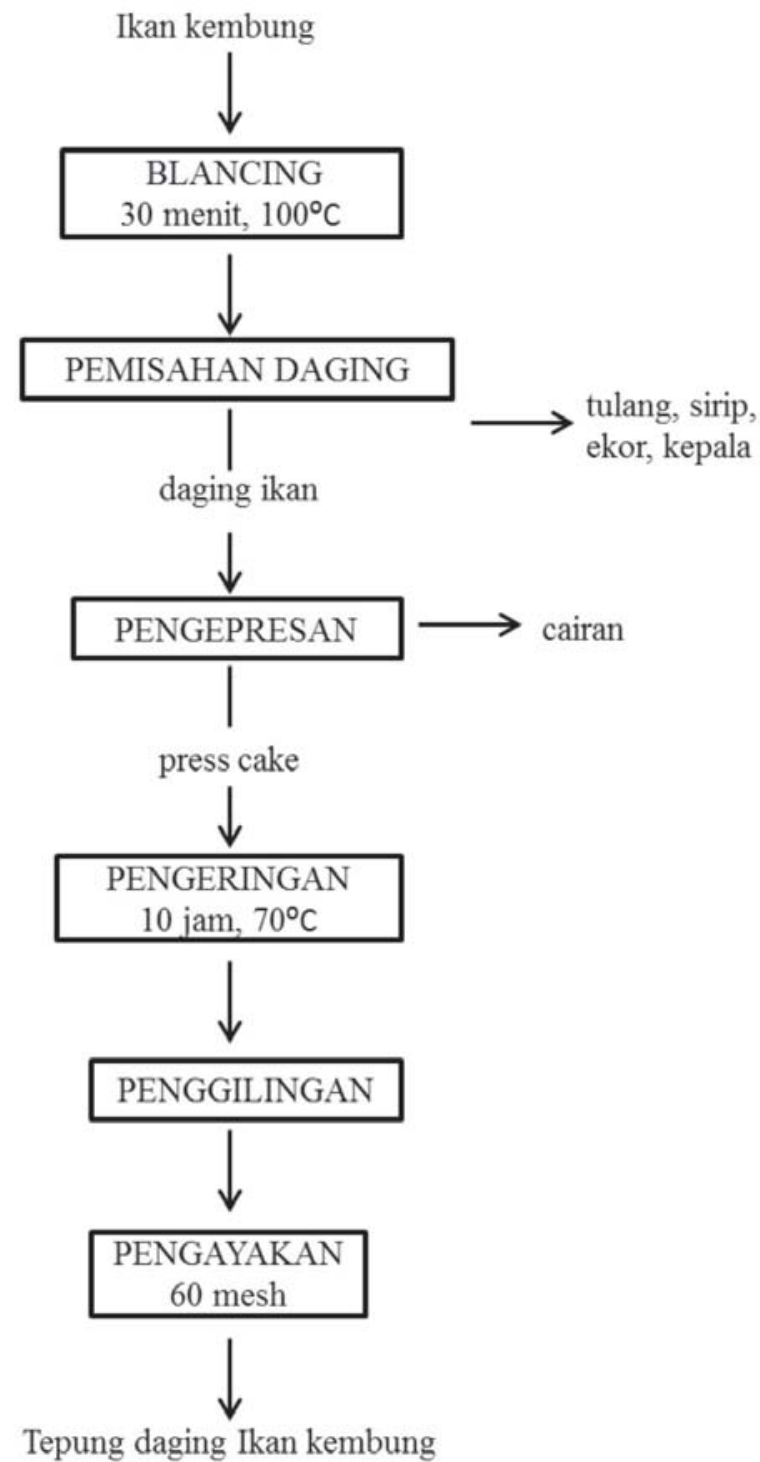

\section{Gambar 1. Diagram Alir Pembuatan Tepung Daging Ikan Kembung}

sangat menentukan kualitas dange yang dihasilkan.

\section{BAHANDAN METODE}

Bahan utama yang digunakan dalam penelitian ini berupa pati sagu yang dibeli di pasar tradisional di Palopo serta ikan kembung yang dibeli di pasar tradisional di Yogyakarta. Bahan lain yang dibutuhkan berupa bahanbahan kimia untuk keperluan analisis. 


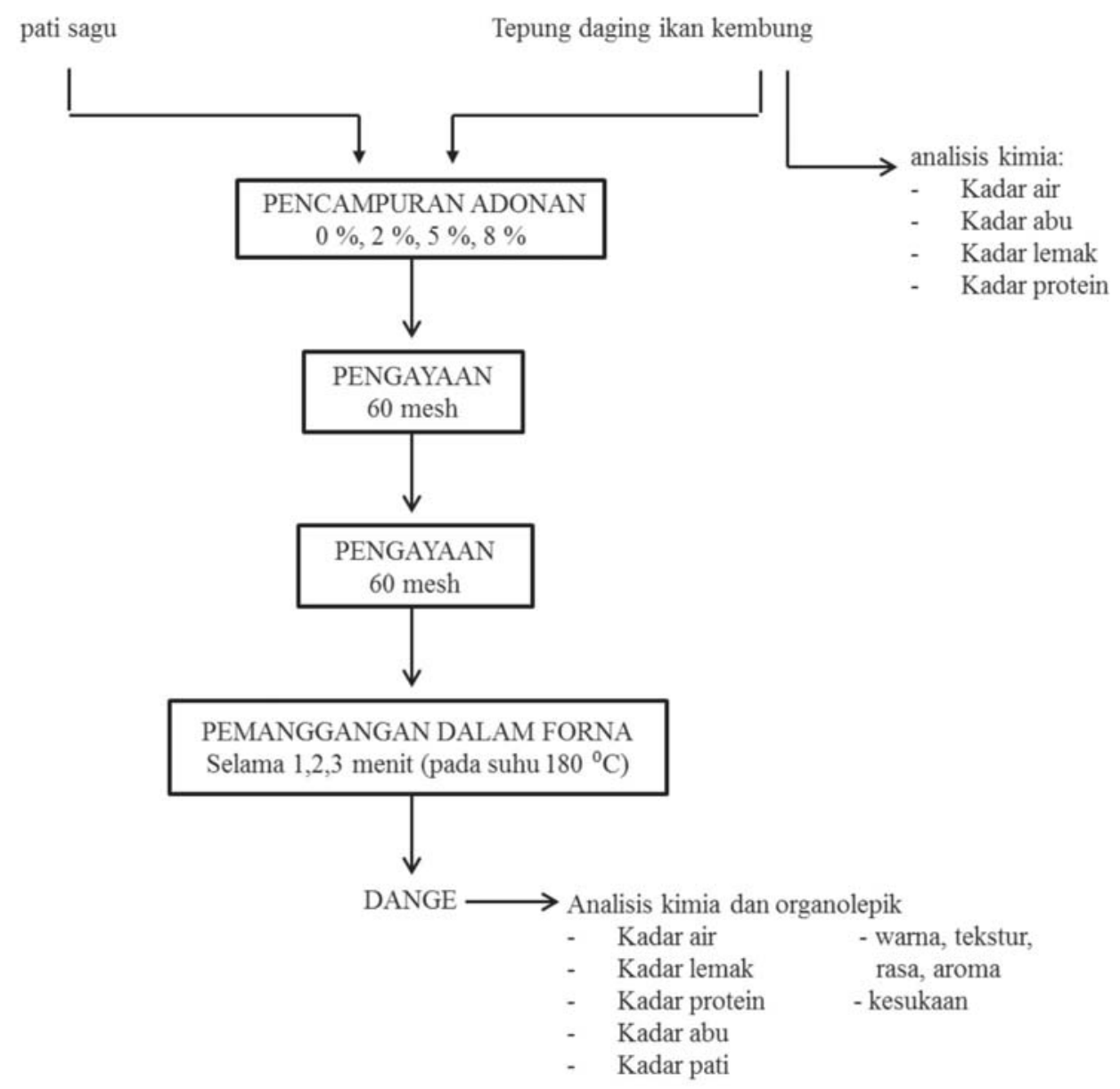

Gambar 2. Diagram Alir Kegiatan Penelitian

Penelitian ini diawali dengan pembuatan tepung daging ikan kembung serta orientasi untuk menentukan variasi konsentrasi tepung daging ikan dan lama waktu pemanggangan dange yang dapat dilaksanakan pada penelitian. Mengacu pada Suharto (2003), tepung daging ikan kembung dibuat dengan cara seperti terlihat pada Garnbar 1.

Berdasarkan hasil orientasi, dilihat dari sifat organoleptiknya setelah proses pemanggangan, yaitu tekstur dan warna pada dange, maka konsentrasi tepung daging ikan yang dapat disubstitusikan adalah 0\%, 2\%, 5\% dan 8\%. Dange yang dihasilkan dari perlakuan dengan substitusi 10\% sangat rapuh, wamanya coklat tua serta aromanya sangat kuat (sangat amis). Waktu pemanggangannya maksimal 3 menit karena lebih dari waktu tersebut, dange sudah nampak gosong. Untuk menilai kualitas dange yang disubstitusi dengan tepung daging ikan kembung, maka dilakukan analisis terhadap tepung daging ikan serta dange yang dihasilkan. Analisis kimia dilakukan terhadap tepung daging ikan, sedangkan analisis kimia dan organoleptik dilakukan terhadap dange.

Analisis kimia yang dilakukan meliputi penentuan : kadar air, kadar lemak, kadar abu, kadar protein serta kadar pati (Sudarmadji dkk., 
1984). Analisis organoleptik dilakukan oleh panelis yang sudah terbiasa mengkonsumsi dange, meliputi uji perbedaan, menggunakan metode scoring test serta uji kesukaan

keseluruhan, menggunakan metode hedonic scale test (Soewamo, 1985). Data yang diperoleh dianalisis menggunakan ANOVA dan jika perlu dilanjutkan dengan DMRT. Pembuatan dange dan kegiatan penelitian ini dapat dilihat pada Gambar2.

\section{HASIL DAN PEMBAHASAN}

Berdasarkan hasil analisis kimia yang dilakukan, tepung daging ikan kembung yang digunakan pada penelitian ini mempunyai komposisi sebagai yang tertera di Tabel 1.Hasil analisis menunjukkan bahwa kandungan utama dalam tepung daging ikan kembung adalah protein, sehingga memang tepat jika digunakan sebagai bahan substitusi untuk meningkatkan kandungan protein dange. Selain itu, ikan kembung mempunyai cita rasa dan aroma yang baik (gurih), sehingga diharapkan dapat meningkatkan cita rasa dan flavor dange yang akan dihasilkan.

Tabel 1. Komposisi Kimia Tepung Daging Ikan Kembung

\begin{tabular}{ll}
\hline PARAMETER & JUMLAH (\% DB) \\
\hline Kadar Air & 4,45 \\
Kadar Lemak & 10,50 \\
Kadar Protein & 75,80 \\
Kadar Abu & 4,15 \\
\hline
\end{tabular}

Hasil penelitian terhadap dange yang disubstitusi dengan tepung daging ikan kembung dan dipanggang pada berbagai variasi waktu menunjukkan bahwa kombinasi perlakuan tersebut mempengaruhi sifat kimia, fisik maupun organoleptik dange yang dihasilkan. Hasil analisisnya dapat diuraikan sebagai berikut:

\section{KadarAir}

Hasil analisis terhadap kadar air dange pada berbagai konsentrasi tepung daging ikan dan lama waktu pemanggangan dapat dilihat pada Tabel 2.

Tabel 2. Hasil Analisis Kadar Air Dange (\%) Pada Berbagai Variasi Substitusi Tepung Daging Ikan Kembung dan Lama Waktu Pemanggangan

\begin{tabular}{|c|c|c|c|c|}
\hline \multirow{2}{*}{$\begin{array}{l}\text { WAKTU } \\
\text { PEMANGGANGAN }\end{array}$} & \multicolumn{4}{|c|}{$\begin{array}{l}\text { Konsentrasi tepung daging } \\
\text { ikan kembung }\end{array}$} \\
\hline & $0 \%$ & $2 \%$ & $5 \%$ & $8 \%$ \\
\hline menit & 24,89 j & $26,71 \mathrm{~g}$ & $27,84 d$ & 29,69 \\
\hline 2 menit & $23,57 \mathrm{k}$ & $25,94 \mathrm{~h}$ & $27,62 \mathrm{e}$ & 28,94 \\
\hline 3 menit & $22,75 \mid$ & $25,06 \mathrm{i}$ & $27,11 \mathrm{f}$ & 28,11 \\
\hline \multicolumn{5}{|c|}{$\begin{array}{l}\text { Tabel 3. Hasil Analisis Kadar Lemak Dange (\% Db) Pada } \\
\text { Berbagai Variasi Substitusi Tepung Daging Ikan } \\
\text { Kembung dan Lama Waktu Pemanggangan }\end{array}$} \\
\hline \multirow{2}{*}{$\begin{array}{l}\text { WAKTU } \\
\text { PEMANGGANGAN }\end{array}$} & \multicolumn{4}{|c|}{$\begin{array}{l}\text { Konsentrasi tepung daging } \\
\text { ikan kembung }\end{array}$} \\
\hline & $0 \%$ & $2 \%$ & $5 \%$ & $8 \%$ \\
\hline 1 menit & $0,03 j$ & $0,32 \mathrm{~g}$ & $0,50 \mathrm{~d}$ & $0,88 \mathrm{a}$ \\
\hline 2 menit & 0,03 i,k & $0,28 \mathrm{~g}, \mathrm{~h}$ & $0,43 \mathrm{e}$ & $0,75 b$ \\
\hline 3 menit & $0,02 i, k$, & $0,26 \mathrm{h,i}$ & $0,38 \mathrm{f}$ & $0,64 c$ \\
\hline
\end{tabular}

Keterangan : Huruf yang mengikuti angka pada tabel di atas menunjukkan adanya perbedaan nyata pada taraf $5 \%$. 
Tabel 4. Hasil Analisis Kadar Protein Dange (\% Db) Pada Berbagai Variasi Substitusi Tepung Daging Ikan Kembung dan Lama Waktu Pemanggangan

\begin{tabular}{lcccc}
\hline \multirow{2}{*}{$\begin{array}{l}\text { WAKTU } \\
\text { PEMANGGANGAN }\end{array}$} & \multicolumn{4}{c}{$\begin{array}{c}\text { Konsentrasi tepung daging } \\
\text { ikan kembung }\end{array}$} \\
\cline { 2 - 5 } & $0 \%$ & $2 \%$ & $5 \%$ & $8 \%$ \\
\hline 1 menit & $0,63 \mathrm{i}$ & $2,14 \mathrm{~g}$ & $3,98 \mathrm{~d}$ & $4,48 \mathrm{a}$ \\
2 menit & $0,54 \mathrm{k}$ & $2,09 \mathrm{~g}, \mathrm{~h}$ & $3,68 \mathrm{e}$ & $4,37 \mathrm{~b}$ \\
3 menit & $0,49 \mathrm{k}, \mathrm{l}$ & $2,03 \mathrm{i}$ & $3,30 \mathrm{f}$ & $4,27 \mathrm{c}$ \\
\hline
\end{tabular}

Keterangan : Huruf yang mengikuti angka pada tabel di atas menunjukkan adanya perbedaan nyata pada tarafá $5 \%$.

Tabel 5. Hasil Analisis Kadar Abu Dange (\% Db) Pada Berbagai Variasi Substitusi Tepung Daging Ikan Kembung dan Lama Waktu Pemangganga

\begin{tabular}{lllll}
\hline WAKTU & \multicolumn{4}{c}{$\begin{array}{c}\text { Konsentrasi tepung daging } \\
\text { ikan kembung }\end{array}$} \\
\cline { 2 - 5 } PEMANGGANGAN & $0 \%$ & $2 \%$ & $5 \%$ & $8 \%$ \\
\hline 1 menit & $1,13 \mathrm{i}$ & $1,56 \mathrm{~g}$ & $2,48 \mathrm{~d}$ & $2,80 \mathrm{a}$ \\
2 menit & $1,12 i, \mathrm{k}$ & $1,45 \mathrm{~h}$ & $2,32 \mathrm{e}$ & $2,74 \mathrm{~b}$ \\
3 menit & $1,11 \mathrm{j}, \mathrm{k}, \mathrm{l}$ & $1,25 \mathrm{i}$ & $2,25 \mathrm{f}$ & $2,65 \mathrm{c}$ \\
\hline
\end{tabular}

Keterangan : Huruf yang mengikuti angka pada tabel di atas menunjukkan adanya perbedaan nyata pada tarafá $5 \%$.

Tabel 6. Hasil Analisis Kadar Pati Dange (\% Db) Pada Berbagai Variasi Substitusi Tepung Daging Ikan Kembung dan Lama Waktu Pemanggangan

\begin{tabular}{lllll}
\hline $\begin{array}{l}\text { WAKTU } \\
\text { PEMANGGANGAN }\end{array}$ & \multicolumn{4}{c}{$\begin{array}{c}\text { Konsentrasi tepung daging } \\
\text { ikan kembung }\end{array}$} \\
\cline { 2 - 5 } & $0 \%$ & $2 \%$ & $5 \%$ & $8 \%$ \\
\hline 1 menit & $73,24 \mathrm{a}$ & $60,68 \mathrm{~d}$ & $57,78 \mathrm{~g}$ & $54,56 \mathrm{i}$ \\
2 menit & $73,06 \mathrm{a}, \mathrm{b}$ & $60,89 \mathrm{~d}, \mathrm{~d}$ & $57,94 \mathrm{~g}, \mathrm{~h}$ & $54,41 \mathrm{i,k}$ \\
3 menit & $73,22 \mathrm{a}, \mathrm{b}, \mathrm{c}$ & $61,16 \mathrm{e}, \mathrm{f}$ & $57,71 \mathrm{~g}, \mathrm{~h}, \mathrm{i}$ & $54,52 \mathrm{i}, \mathrm{k}, \mathrm{l}$ \\
\hline
\end{tabular}

Keterangan : Huruf yang mengikuti angka pada tabel di atas menunjukkan adanya perbedaan nyata pada tarafá $5 \%$.
Tabel 2 tersebut menunjukkan adanya pengaruh nyata dari konsentrasi tepung daging ikan yang disubstitusikan dan lama waktu pemanggangan terhadap kadar air dange. Kadar air dange setelah dipanggang mengalami peningkatan dengan bertambahnya konsentrasi tepung daging ikan yang disubstitusikan. Akan tetapi, semakin lama dange dipanggang, kadar airnya semakin berkurang.

Semakin banyak tepung daging ikan yang disubstitusikan, berarti semakin banyak protein yang terkandung dalam dange dan akan menyebabkan semakin tinggi kadar aimya. Hal ini terjadi karena protein merupakan komponen utama yang berperan terhadap pengikatan air. Menurut Winarno (1984), sebagian besar protein mengandung sisi rantai polar, sehingga rnenyebabkan senyawa tersebut bersifat hidrofilik (mengikat air). Oleh karena itu, semakin tinggi kandungan protein yang berasal dari substitusi tepung daging ikan, maka kadar air dange semakin meningkat. Pada saat dilakukan pemanggangan, sebagian air tersebut mengalami penguapan. Oleh karena itu, semakin lama dipanggang, maka kadar airnya semakin menurun.

\section{Kadar Lemak}

Hasil analisis terhadap kadar lemak dange pada berbagai konsentrasi tepung daging ikan dan lama waktu pemanggangan dapat dilihat pada Tabel 3.Tabel 3 tersebut menunjukkan adanya pengaruh nyata antara konsentrasi tepung daging ikan kembung dan waktu pemanggangan terhadap kadar lemak dange. Pada penelitian ini, kadar lemak tepung daging ikan 10,5\% sedangkan dalam sagu 0,2\%. Oleh karena itu, semakin banyak tepung daging ikan yang disubstitusikan akan meningkatkan kadar lemak dange. Namun, proses pemanggangan 
yang dilakukan akan mengakibatkan lemak mengalami drip dan viskositasnya turun, sehingga kadar lemak dalam dange tersebut turun karena mencair dan keluar dari adonan. Hal ini terlihat pada dasar dan tepi forna yang menjadi berminyak setelah digunakan untuk memanggang. Oleh karena itu, semakin lama dange dipanggang, maka kadar lemaknya semakin rendah.

\section{Kadar Protein}

Hasil analisis terhadap kadar protein dange pada berbagai konsentrasi tepung daging ikan dan lama waktu pemanggangan dapat dilihat pada Tabel 4.Tabel 4 tersebut menunjukkan adanya pengaruh nyata antara konsentrasi tepung daging ikan kembung dan waktu pemanggangan terhadap kadar protein dange. Kadar protein dange semakin meningkat dengan meningkatnya konsentrasi tepung daging ikan yang disubstitusikan, tetapi sernakin menurun dengan semakin lamanya waktu pemanggangan.Pada penelitian ini, kadar protein tepung daging ikan 75,8\% sedangkan dalam sagu 0,7\%. Oleh karena itu, semakin banyak tepung daging ikan yang disubstitusikan, makakadar protein dange menjadi semakin tinggi. Akan tetapi, proses pemanggangan yang dilakukan akan menyebabkan protein terdenaturasi dan sebagian nitrogennya menguap (Suhardi, 1988). Oleh karena itu, semakin lama adonan dange dipanggang, maka kadar proteinnya semakin rendah.

\section{Kadar Abu}

Hasil analisis terhadap kadar abu dange pada berbagai konsentrasi tepung daging ikan dan lama waktu pemanggangan dapat dilihat pada Tabel 5.Tabel 5 tersebut menunjukkan adanya pengaruh nyata antara konsentrasi tepung daging ikan kembung dan waktu pemanggangan terhadap kadar abu dange. Kadar abu mencerminkan kandungan mineral dalam produk tersebut. Mineral dalam ikan jauh lebih banyak dibanding dalam sagu. Oleh karena itu, semakin banyak tepung daging ikan yang disubstitusikan, maka kadar abu dange menjadi semakin tinggi. Akan tetapi, semakin lama waktu pemanggangannya, maka kadar abu dange menjadi semakin rendah. Hal ini terjadi karena selama dilakukan proses pembakaran, anion organik mengalami kerusakan dan beberapa mineral diubah menjadi oksidanya. Menurut John (1997), mineral yang berupa logam dan beberapa garam dapat berkurang atau hilang karena penguapan selama pemanggangan.

\section{Kadar Pati}

Hasil analisis terhadapkadarpati dange pada berbagai konsentrasi tepung daging ikan dan lama waktu pemanggangan dapat dilihat pada Tabel 6. Tabel tersebut menunjukkan adanya pengaruh nyata antara konsentrasi tepung daging ikan kembung dan waktu pemanggangan terhadap kadar pati dange. Komponen utama sagu adalah pati. Oleh karena itu semakin banyak tepung daging ikan yang disubstitusikan, maka kadar $\mathrm{p}^{\sim}$ ti dalam dangesemakin rendah. Semakin lama waktu pemanggangan dange yang dilakukan menyebabkan gelatinisasi pati semakin sempurna dan sebagian kecil pati terhidrolisis, sehingga kadar pati dalam dange sedikit berkurang.

\section{Sifat Organoleptik Dange}

Analisis organoleptik dilakukan terhadap dange setelah dipanggang, diuji oleh panelis yang sudah terbiasa mengkonsumsi dange. Analisis meliputi uji pembedaan (warna, tekstur, 
rasa, aroma) serta kesukaan secara keseluruhan. Hasil analisis menunjukkan bahwa nilai warna dange berkisar antara putih (nilai 1,04) sampai coklat (nilai 3,6). Secara statistik, variasi konsentrasi tepung daging ikan yang disubstitusikan dan waktu pemanggangan berpengaruh nyata terhadap wama dange. Semakin banyak tepung daging ikan yang disubstitusikan, warna dange semakin coklat. Hal tersebut berkaitan dengan kandungan protein dange (Tabel 4). Warna coklat dange terjadi akibat reaksi Maillard, yaitu reaksi antara protein/gugus amin dengan gula reduksi yang terkandung dalam dange. Reaksi tersebut menghasilkan senyawa berwarna coklat yang disebut melanoidin (Winarno, 1984). Pada uji kesukaan, warna coklat dange ternyata tidak disukai karena dinilai kurang menarik dan terkesan gosong, jauh berbeda dari warna dange yang biasanya putih.

Tekstur dange semakin rapuh dan mudah hancur dengan semakin banyaknya tepung daging ikan yang disubstitusikan serta semakin lamanya waktu pemanggangan. Tekstur berkaitan dengan kandungan protein dan pati dalam adonan. Saat dilakukan pencampuran adonan, protein dari tepung daging ikan berada di luar granula-granula pati sagu dan merata dalam adonan. Pada saat dilakukan pemanggangan, adonan mengalami gelatinisasi dan terjadi diskontinuitas antara protein dan pati. Hal tersebut mengakibatkan renggangnya ikatan-ikatan antar pati saat mengalami retrogradasi (Meyer, 1973), sehingga dihasilkan tekstur yang semakin rapuh dengan semakin banyaknya tepung daging ikan yang disubstitusikan. Pada uji kesukaan, yang paling disukai adalah dange yang dibuat dari substitusi 5\% dengan waktu pemanggangan 1 menit, mempunyai tekstur agak rapuh.
Variasi konsentrasi tepung daging ikan yang disubstitusikan serta lama waktu pemanggangan berpengaruh nyata pada rasa dan aroma dange yang dihasilkan. Rasa dange berkisar antara tawar (nilai 4,56) sampai sangat rasa ikan (nilai 2,2). Sementara aroma dange berkisar antara sangat tidak kuat (nilai 1,4) sampai kuat (nilai 4,36). Semakin banyak tepung daging ikan yang disubstitusikan serta semakin lama waktu pemanggangannya, maka rasa dan aroma (flavor) ikan semakin kuat. Flavor tersebut dibentuk oleh komponen nitrogen yang terdapat dalam protein daging ikan. Timbulnya flavor khas pada daging yang dimasak disebabkan oleh pemecahan asam amino, karbohidrat dan lemak (Price, 1970; Soeparno, 1992). Pada dange, hal tersebut terjadi saat dilakukan proses pemanggangan. Pada uji kesukaan, dange yang paling disukai adalah yang dibuat dari substitusi 5\% dengan waktu pemanggangan 1 menit, mempunyai rasa ikan (nilai 2,6) dan aroma agak kuat (nilai 3,36).

\section{SIMPULAN}

Berdasarkan uraian di atas, dapat disimpulkan bahwa semakin tinggi konsentrasi tepung daging ikan yang disubstitusikan, maka kadar air, protein, lemak dan abu akan semakin meningkat, tetapi kadar patinya semakin menurun. Semakin lama waktu pemanggangan, maka kadar air, protein, lemak dan abu akan semakin berkurang. Secara fisik, tekstur dange menjadi semakin rapuh dan warna semakin coklat. Secara organoleptik, cita rasa dan aroma ikan menjadi semakin kuat setelah proses pemanggangan.

Dange yang dibuat dengan substitusi 5\% tepung daging ikan dan waktu pemanggangan 1 menit merupakan dange yang paling disukai panelis. Dange tersebut mempunyai 
karakteristik tekstur agak rapuh, warna putih kekuningan, cita rasa ikan serta aroma khas ikan agak kuat dengan kadar air 27,84\% ; kadar protein 3,98\% db ; kadar lemak 0,50\% db ; kadar abu 2,48\% db dan kadar pati 57,78\% db.

\section{DAFTAR PUSTAKA}

Budi, H. 1986. Budi daya dan pengolahan sagu. Kanisius, Yogyakarta.

Meyer, L.H. 1973. Food chemistry. Reinhold Publishing Co., New York.

Pangloli, P. dan Bambang H. 1992. Potensi dan pemanfaatan sagu. Kanisius, Yogyakarta.

Price, J.F. 1970. The science of meat and meat product. Second edition. W.H. Freeman and Company, San Francisco-USA.

Soeparno. 1992. Ilmu dan teknologi daging. Gadjah Mada University Press, Yogyakarta.

Soewarno,T.S. 1985. Penilaian organoleptik untuk industri pangan dan hasil pertanian. Bhratara Karya Aksara, Jakarta.

Sudarmadji, S., B. Haryono dan Suhardi. 1984. Prosedur analisa untuk bahan makanan dan pertanian. Liberty, Yogyakarta.

Suhardi. 1988. Kimia dan teknologi protein. PAU Pangan dan Gizi, UGM, Yogyakarta.

Suharto. 2003. Studi pembuatan tepung daging dan limbah ikan nila (Oreochromis nilotica) dengan berbagai waktu perebusan terhadap kualitas tepung ikan yang dihasilkan. Skripsi, Fakultas Teknologi Pertanian, Universitas Widya Mataram Yogyakarta. Winarno, F.G. 1984. Kimia Pangan dan Gizi. Gramedia, Jakarta. 